\begin{tabular}{lccc} 
VERSITA & GOSPODARKA & SUROWCAMI & MINERALNYMI \\
\hline \multirow{2}{*}{ Tom 29} & 2013 & Zeszyt 4 \\
& & DOI 10.2478/gospo-2013-0048 &
\end{tabular}

\title{
Characteristics of selected wastes from carbon gasification
}

\section{Introduction}

Gasification is included among various so called "clean coal" technologies, and is one of the most promising methods of using these conventional fuels - hard coal and lignite.

Coal gasification is a commercially applicable method. At present, it is being tested in experimental installations with a power output of 50-600 MW (Pérez-Fortes et al. 2009). In Poland this technology is planned for implementation on the on an industrial scale technical scale.

Despite having many advantages, coal gasification nevertheless produces waste. That is why in considering the possibilities for commercial implementation of this technology, consideration must be given to the occurrence of its wastes - slag and fly ash. These wastes contain a high content of $\mathrm{SiO}_{2}$ (Table 1 and 2), especially slag and ash from coal and petroleum coke gasification, where $\mathrm{SiO}_{2}$ content reaches a level of $50 \%$.

The wastes from the gasification process are, in general, the kind of wastes included into group 10 - wastes from thermal processes; and subgroup 1001 - wastes from power stations and other plants of fuels combustion. However, because of the use of gasification technology, the properties of the obtained wastes may differ from currently produced wastes.

In a gasification installation, it is possible to use alternative fuels such as petroleum coke, fuels from wastes of RDF type (Refused Derived Fuel), or bio-mass. The result is a reduction in the cost of energy production and the cost of waste storage.

* Professor, ** Ph.D. Eng., *** Ph.D.Sc. Eng., AGH University of Science and Technology, Kraków, Poland; e-mail: mamaz@agh.edu.pl 
Chemical composition of ash from different installations of a steam-gas block with integrated fuel gasification [wt. \%]

TABELA 1

Skład chemiczny popiołów z różnych instalacji bloku gazowo-parowego ze zintegrowanym zgazowaniem paliwa [\% mas.]

\begin{tabular}{|c|c|c|c|c|c|}
\hline \multirow{4}{*}{$\begin{array}{c}\text { Chemical compound } \\
\text { Loss on ignition }\left(1000^{\circ} \mathrm{C}\right)\end{array}$} & \multicolumn{5}{|c|}{ Chemical composition of ash from gasification } \\
\hline & \multirow{3}{*}{$\begin{array}{c}\text { coal } \\
\text { Song et al. } \\
2009 \\
\text { N/A }\end{array}$} & \multicolumn{4}{|c|}{ coal and coke from petroleum refining } \\
\hline & & \multirow{2}{*}{$\begin{array}{c}\begin{array}{r}\text { Aineto et al. } \\
2005,2006 a\end{array} \\
\text { N/A }\end{array}$} & \multirow{2}{*}{$\begin{array}{c}\begin{array}{c}\text { Aineto et al. } \\
2006 \mathrm{~b}\end{array} \\
3.47\end{array}$} & \multicolumn{2}{|c|}{ Font et al. 2005} \\
\hline & & & & $\mathrm{N} / \mathrm{A}$ & $\mathrm{N} / \mathrm{A}$ \\
\hline $\mathrm{SiO}_{2}$ & 43.67 & 56.47 & 54.35 & 56.7 & 61.6 \\
\hline $\mathrm{Al}_{2} \mathrm{O}_{3}$ & 28.69 & 24.13 & 23.22 & 18.8 & 19.2 \\
\hline $\mathrm{Fe}_{2} \mathrm{O}_{3}$ & 17.77 & 3.99 & 3.84 & 3.8 & 3.9 \\
\hline $\mathrm{TiO}_{2}$ & 1.39 & 0.54 & 0.67 & 0.5 & 0.5 \\
\hline $\mathrm{CaO}$ & 3.55 & 3.64 & 3.5 & 6.4 & 3.0 \\
\hline $\mathrm{MgO}$ & 0.82 & 0.68 & 0.65 & 0.8 & 0.6 \\
\hline $\mathrm{SO}_{3}$ & 2.82 & 1.39 & b.d. & 1.2 & 1.1 \\
\hline $\mathrm{Na}_{2} \mathrm{O}$ & 0.40 & 0.70 & 0.6 & 0.6 & 0.5 \\
\hline $\mathrm{K}_{2} \mathrm{O}$ & 0.91 & 4.05 & 3.9 & 3.3 & 3.3 \\
\hline
\end{tabular}

The introduction of gasification technology results in the production of a new kind of waste which should be examined and classified to find a way to manage it or store it in an ecologically safe way. At present, knowledge of gasification wastes is rather limited because they originate mainly from pilot installations.

Amorphous phase is a basic phase for slag and ash from coal gasification, coal and petroleum coke gasification, and coal and bio-mass gasification. In the ash from coal and petroleum coke gasification there is a small quantity of the sulphides $\mathrm{PbS}, \mathrm{ZnS}$, and FeS. The presence of hematite $\left(\mathrm{Fe}_{2} \mathrm{O}_{3}\right)$, mullite $\left(3 \mathrm{Al}_{2} \mathrm{O}_{3} \cdot 2 \mathrm{SiO}_{2}\right)$, hercynite $\left(\mathrm{FeO} \cdot \mathrm{Al}_{2} \mathrm{O}_{3}\right)$, and anorthite $\left(\mathrm{CaO} \cdot \mathrm{Al}_{2} \mathrm{O}_{3} \cdot \mathrm{SiO}_{2}\right)$ have been proven (Aineto et al. 2005, 2006a, b). This ash, according to the work of Aineto et al. (2006b), can be classified as ash of class $\mathrm{F}$ $\left(\mathrm{SiO}_{2}+\mathrm{Al}_{2} \mathrm{O}_{3}+\mathrm{Fe}_{2} \mathrm{O}_{3}-\max .70 \% ; \mathrm{SO}_{3}-\right.$ max. 5.0\%; Loss on ignitron - max. 6; Moisture content - max. 3.0\%) according to ASTM C 618 Standard Specification for Coal Fly Ash and Raw or Calcined Natural Pozzolan for Use in Concrete.

In the ash from coal gasification, some phases have been found similar to those appearing in wastes from conventional boilers, such as quartz $\left(\mathrm{SiO}_{2}\right)$, anhydrite $\left(\mathrm{CaSO}_{4}\right)$, calcite $\left(\mathrm{CaCO}_{3}\right)$, hematite $\left(\mathrm{Fe}_{2} \mathrm{O}_{3}\right)$, and mullite $\left(3 \mathrm{Al}_{2} \mathrm{O}_{3} \cdot 2 \mathrm{SiO}_{2}\right)$ (Tang et al. 2010). 
TABLE 2

Chemical composition of slag from different installations of a steam-gas block with integrated fuel gasification [wt. \%]

TABELA 2

Skład chemiczny żużli z różnych instalacji bloku gazowo-parowego ze zintegrowanym zgazowaniem paliwa [\% mas.]

\begin{tabular}{|c|c|c|c|c|c|c|c|c|}
\hline \multirow{3}{*}{$\begin{array}{l}\text { Chemical } \\
\text { compound }\end{array}$} & \multicolumn{8}{|c|}{ Chemical composition of slag from gasification } \\
\hline & \multicolumn{5}{|c|}{ coal and coke from petroleum refining } & \multicolumn{3}{|c|}{ coal } \\
\hline & $\begin{array}{l}\text { Acosta } \\
\text { et al. } 2001\end{array}$ & $\begin{array}{c}\text { Acosta } \\
\text { et al. } 2002 \mathrm{a}\end{array}$ & $\begin{array}{c}\text { Acosta } \\
\text { et al. 2002b }\end{array}$ & $\begin{array}{l}\text { Aineto } \\
\text { et al. } 2005\end{array}$ & $\begin{array}{c}\text { Aineto } \\
\text { et al. } 2006\end{array}$ & $\begin{array}{l}\text { Song et al. } \\
2009\end{array}$ & $\begin{array}{l}\text { Song et al. } \\
2010\end{array}$ & $\begin{array}{c}\text { Tang et al. } \\
2010\end{array}$ \\
\hline $\begin{array}{l}\text { Loss on } \\
\text { ignition } \\
\left(1000^{\circ} \mathrm{C}\right)\end{array}$ & - & - & 2.64 & 0.34 & 0.34 & - & - & 25.69 \\
\hline $\mathrm{SiO}_{2}$ & 56.7 & 57.27 & 56.93 & 55.12 & 55.12 & 41.16 & 46.55 & 40.83 \\
\hline $\mathrm{Al}_{2} \mathrm{O}_{3}$ & 21.8 & 23.01 & 18.77 & 28.20 & 28.20 & 15.69 & 26.04 & 11.76 \\
\hline $\mathrm{Fe}_{2} \mathrm{O}_{3}$ & 4.8 & 5.67 & 4.38 & 5.77 & 5.77 & 12.60 & 3.30 & 6.46 \\
\hline $\mathrm{TiO}_{2}$ & 0.6 & 8.39 & 0.47 & - & 0.76 & 0.77 & 1.14 & \\
\hline $\mathrm{CaO}$ & 9.3 & - & 11.44 & 6.04 & 6.04 & 26.04 & 20.58 & 9.36 \\
\hline $\mathrm{MgO}$ & 1.0 & - & 0.97 & 0.93 & 0.93 & 1.34 & 0.96 & 1.04 \\
\hline $\mathrm{SO}_{3}$ & 1.4 & 1.48 & 1.81 & 0.51 & 0.51 & - & 0.23 & 0.72 \\
\hline $\mathrm{Na}_{2} \mathrm{O}$ & 0.3 & - & 0.33 & 0.40 & 0.4 & 1.39 & 0.33 & 1.20 \\
\hline $\mathrm{K}_{2} \mathrm{O}$ & 2.1 & - & 1.7 & 2.39 & 2.38 & 1.01 & 0.87 & 1.75 \\
\hline
\end{tabular}

This article presents the results of research on ash and slag characteristics, determining their chemical and phase composition (by means of X-ray diffraction analysis and thermal analysis method) and microstructure.

\section{Results of research}

\subsection{Chemical composition}

Because of the small number of existing coal gasification installations worldwide, the general knowledge regarding the wastes from the process is not sufficient, and due to lack of testing in Poland (domestic installations are in the experimental phase), all research has been conducted on the basis of foreign materials and data.

This analysis used the wastes from two different coal gasification installations. These installations use coal and petroleum coke, and coal with biomass as fuels. The following 
three samples have been tested: 1. ash (ACB) and slag (SBC) from coal and biomass (wood chips from recycled fresh wood, bark, and hard and soft board residues) gasification; 2. waste from the pulverised coal power plant of Electrabel in Belgium, equipped with an atmospheric CFB gasifier using air; and 3. slag from coal, and oil shale gasification (SCO) wastes from the Integrated Gasification in the Combined Cycled power plant ELCOGAS S.A. in Puertollano. Their respective chemical compositions have been determined in detail.

The tested samples demonstrated a high content of $\mathrm{SiO}_{2}$, over $53 \%$ (Table 3), confirming the results obtained by other authors (Table 1 and 2). A low content of $\mathrm{CaO}$ and the lack of free $\mathrm{CaO}$ is distinctive for these wastes. The low content of $\mathrm{CaO}$ and free $\mathrm{CaO}$ may indicate a lack of the binding properties typical for the tested wastes. This is why it may be assumed that these wastes could not be used in the technologies employing conventional ash from coal combustion processes (Kołodziejczyk et al. 2012; Piotrowski 2008).

The chemical composition of tested waste (wt. \%)

Skład chemiczny badanych odpadów (\% mas.)

\begin{tabular}{||c|c|c|c|}
\hline \hline Chemical compound & $\mathrm{ACB}$ & $\mathrm{SCB}$ & SCO \\
\hline \hline $\mathrm{SiO}_{2}$ & 65.10 & 53.10 & 57.00 \\
\hline $\mathrm{Al}_{2} \mathrm{O}_{3}$ & 14.90 & 19.20 & 23.50 \\
\hline $\mathrm{Fe}_{2} \mathrm{O}_{3}$ & 6.65 & 12.85 & 6.70 \\
\hline $\mathrm{TiO}_{2}$ & 0.65 & 0.80 & 0.70 \\
\hline $\mathrm{ghtCaO}^{\mathrm{MgO}}$ & 4.05 & 9.30 & 8.00 \\
\hline $\mathrm{SO}_{3}$ & 1.95 & 2.00 & 1.45 \\
\hline $\mathrm{Na}_{2} \mathrm{O}$ & 0.33 & 0.28 & 0.25 \\
\hline $\mathrm{K}_{2} \mathrm{O}$ & 1.54 & 0.80 & 0.43 \\
\hline $\mathrm{CaO}_{\mathrm{f}}$ & 3.27 & 1.43 & 0.90 \\
\hline Loss on ignition & 0.00 & 0.00 & 0.00 \\
\hline \hline
\end{tabular}

The chemical composition the SCB and SCO slag could be classified as alkaline slag of a chemical composition similar to silica fly ash from lignite combustion, and the ACB fly ash reveals a chemical composition similar to silica fly ash from hard coal.

\subsection{Phase composition}

X-ray diffraction and differential thermal analysis (DTA) methods were used to mark the phase composition of the wastes. 
The phase composition marking was conducted with the use of X-ray diffraction by the powder method of Debye-Sherrer-Hull. The measurement was conducted for the angular range $5-60^{\circ} 2 \Theta \mathrm{CuK} \alpha$. The thermogravimetric testing was carried out using the Derivatograph of Paulik-Paulik-Erdej OD-2. The measurement was made in an air atmosphere. The speed of heating was constant, holding at $10^{\circ} \mathrm{C} \cdot \mathrm{min}^{-1}$. All the tested samples, with a weight of $60 \mathrm{mg}$ or $90 \mathrm{mg}$, were heated in a platinum pot from the ambient temperature to $1000^{\circ} \mathrm{C}$. Observations of the grains morphology were conducted using the scanning microscope Nova 200 Nano SEM made by FEI, equipped with a microanalyser of the characteristic radiation energy EDS, by EDAX-Link, enabling the point chemical analysis.

The phase composition testing by the X-ray diffraction method showed only substances of amorphous character (no reflections from crystal substances on the heightened amorphous background), as shown in the diffractograms in Figure 1. This was confirmed by the results of the phase composition testing conducted with the thermogravimetric (DTA) method. These results showed only stable amorphous phase - there are no exothermic peaks related to recrystallization (Fig. 2). However, the obtained results differ from those obtained by other authors, because in the tested wastes only the amorphous phase was determined (Acosta et al. 2001, 2002; Aineto et al. 2006; Song et al. 2009, 2010).

The DTA curves provided information regarding to the chemical composition of the samples - there are see the endothermic effects in range of thermal decomposition, likely

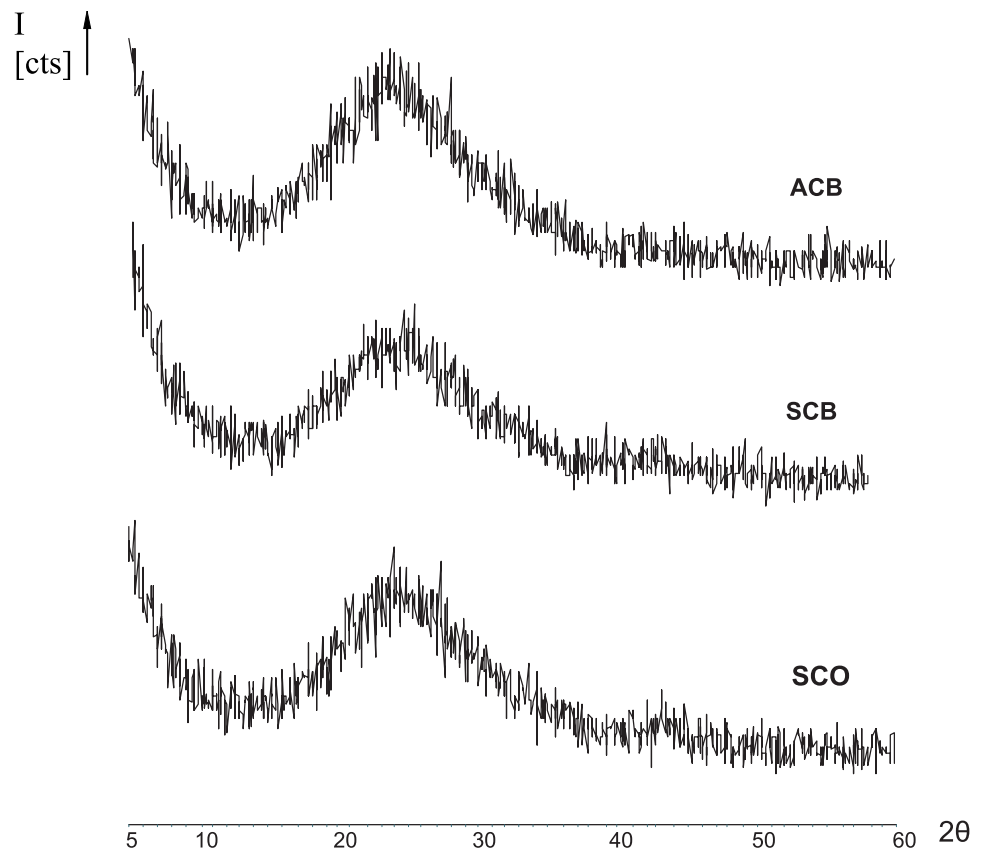

Fig. 1. Diffractograms of the tested wastes from coal gasification (lines artificially spaced)

Rys. 1. Dyfraktogramy badanych odpadów ze zgazowania węgla (linie sztucznie rozsunięte) 


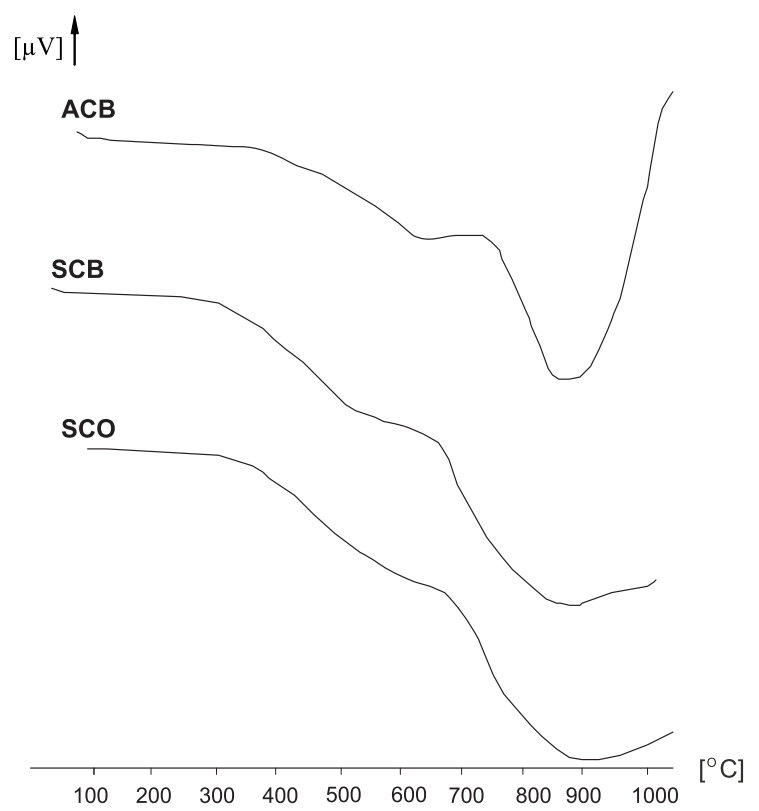

Fig. 2. Thermal analysis curve DTA of the tested wastes from coal gasification (lines artificially spaced)

Rys. 2. Krzywe analizy termicznej DTA badanych odpadów ze zgazowania węgla (linie sztucznie rozsunięte)

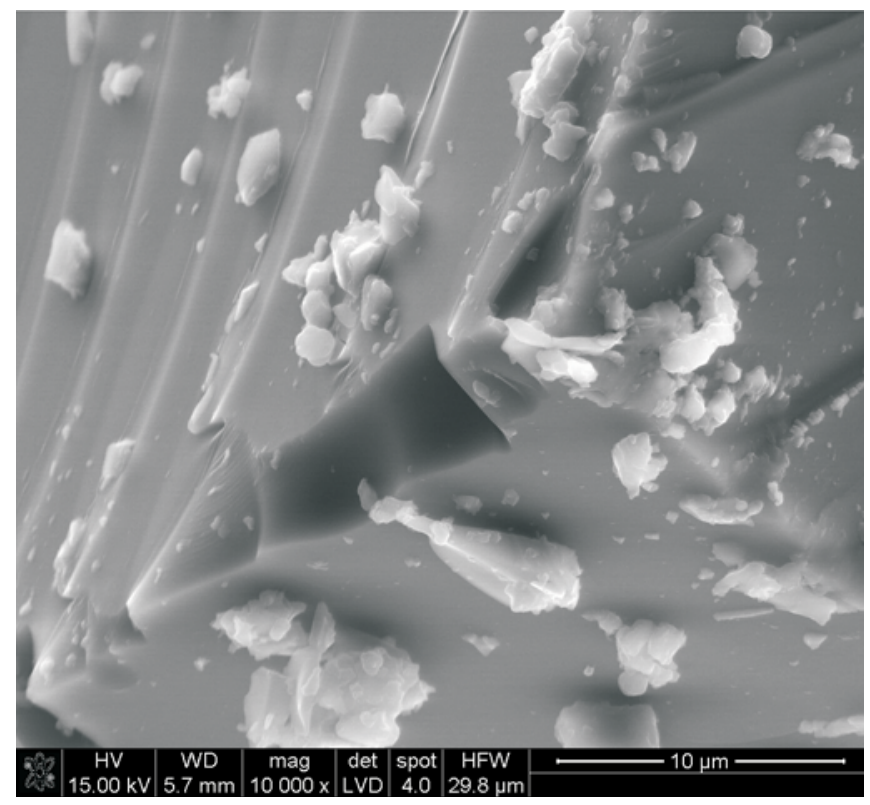

Fig. 3. Microstructure of SCB (SEM)

Rys. 3. Mikrostruktura żużla SCB (SEM) 
dehydroxylation and desulfurization; exothermic effect above $900^{\circ} \mathrm{C}$ is probably related with synthesis occurring in the system.

The presence of amorphous phase only, the result of phase composition, is also confirmed by analysis using scanning microscopy (SEM) (Fig. 3 and 4). The average composition of the analyzed samples corresponds to typical composition siliceous glassy phase in the fly ashes.
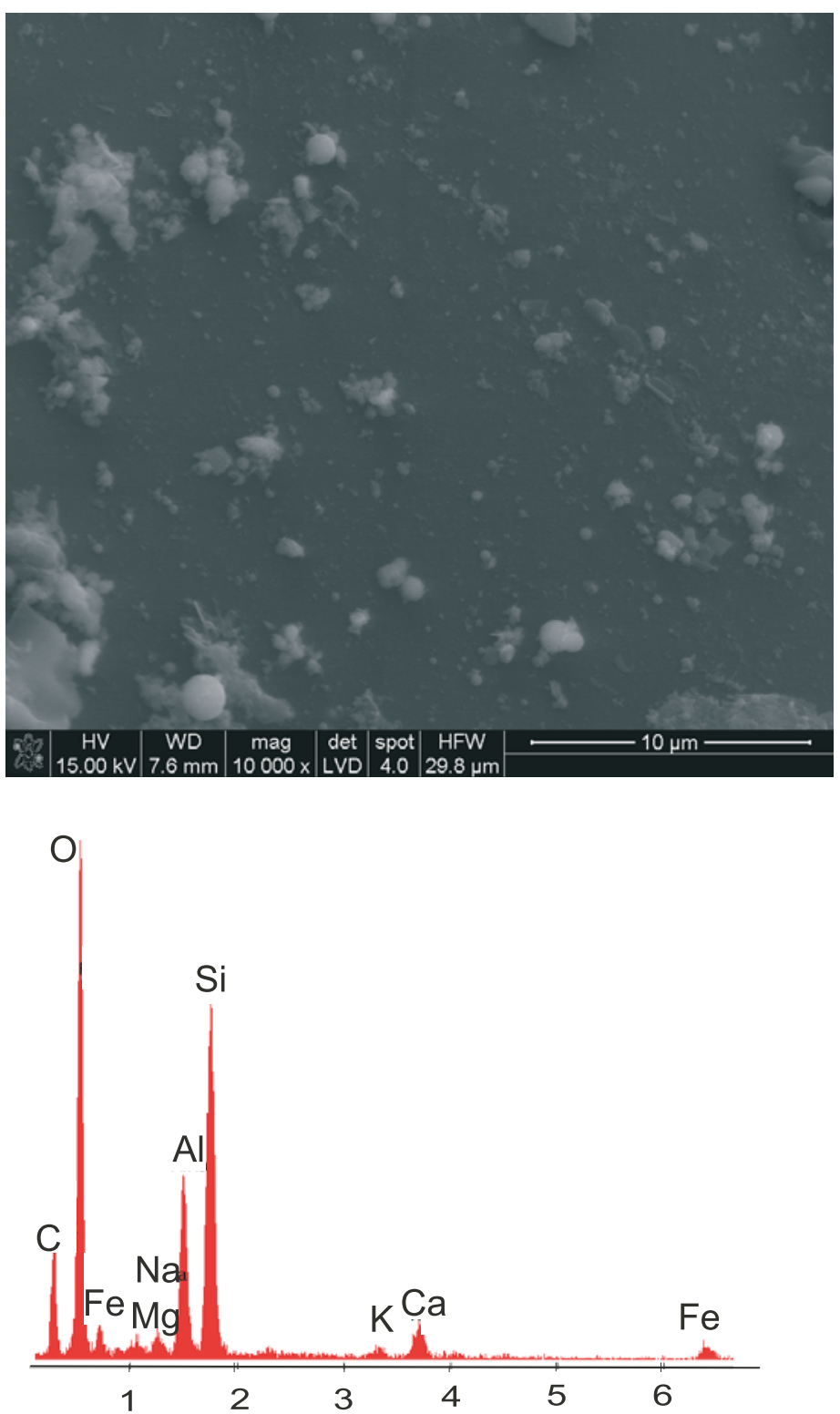

Fig. 4. Microstructure of SCB (SEM) with analysis of typical composition in microareas (EDS)

Rys. 4. Mikrostruktura żużla SCB (SEM) wraz z analizą przeciętnego składu próbki (EDS) 


\begin{abstract}
Summary
It should be pointed out that the research was conducted on wastes originating from foreign pilot installations. Wastes from coal gasification are known to be very specific. They differ in the byproducts of combustion - their properties coming from both conventional and fluidal bed boilers. The phase composition test wastes showed only substances of an amorphous character. This research can provide only introductory recognition of the coal gasification wastes, as it can be assumed that their properties depend on the type of the combusted coal and the technology used. The co-combustion of bio-mass or the other wastes may influence their properties. In the case of the implementation of this technology in Poland, it may occur that the wastes, because of the specific properties of the local coal, along with the use of the chosen technology, might show slightly different properties.
\end{abstract}

The results of the research presented in the article have been prepared within the research project of the Ministry of Education no N N524 361038 "Testing the slag from installations for high temperature coal gasification and its use in mining technology".

\title{
REFERENCES
}

Acosta et al. 2001 - Acosta A., A ineto M., Iglesias I., Romero M., Rincón J.Ma., 2001 Physico-chemical characterization of slag waste coming from IGCC thermal power plant. Material Letters 50 , p. 246-250.

Acosta et al. 2002a - A costa A., Ig les i a s I., A in e to M., R o mero M., R in cón J.Ma., 2002a-Utilisation of IGCC slag and clay steriles in soft mud bricks (by pressing) for use in building bricks manufacturing. Waste Management 22, p. 887-891.

Acosta et al. 2002b - A c os t a A., I gles i a I., A in e to M., R o mero M., R in còn J.M., 2002b-Thermal and sintering characterization of IGCC slag. Journal of Thermal Analysis and Calorimetry 67, p. 249-255.

Aineto et al. 2005 - A in e to M., A c ost a A., R incòn J.M., R o m e r o M., 2005 - Production of lightweight aggregates from coal gasification fly ash and slag. World of Coal Ash (WOCA), 2005, Lexington, USA, 2005. www.flyash.info

Aineto et al. 2006a - A in e to M., A c o s ta A., R in còn J.M., R o me ro M., 2006a-Thermal expansion of slag and fly ash from coal gasification on IGCC power plant. Fuel 85, p. 2352- 2358.

Aineto et al. 2006b - A in e to M., A costa A., Ig les i as I., 2006b - The role of a coal gasification fly ash as clay additive in building ceramic. Journal of European Ceramic Society, 26, p. 3783-3787.

Arroyo et al. 2009 - Arroyo F., Font O., Fernández-Periera C., Querol X., Juan R., Ruiz C., Coca P., 2009 - Germanium recovery from gasification fly ash: Evaluation of end-products obtained by precipitation methods. Journal of hazardous Materials 167, p. $582-588$.

Font et al. 2005 - Font O., Querol X., Huggins F.E., Chimenos J.M., Fernández A.I., Burgos S., P eń a F.G., 2005 - Speciation of major and selected trace elements in IGCC fly ash. Fuel 84, p. 1364-1371.

Kołodziejczyk et al. 2012 - Kołodziejczyk U., Ćwiąkała M., Widuch A., 2012 - Use of fly-ash for the production of hydraulic binding agents and for soil stabilization. Mineral Resources Management (Gospodarka Surowcami Mineralnymi) t. 28, z. 4, s. 15-28.

Pérez-Fortes et al. 2009 - Pérez-Fortes M., Bojarski A.D., V elo E., Nougués J.M., Puigjaner L., 2009 - Conceptual model and evaluation of generated power and emissions in an IGCC plant. Energy 34, p. 1721-1732. 
Pi o trowski Z., 2008 - Properties of wet fly ash suspensions seasoned in hard coal mine underground. Mineral Resources Management (Gospodarka Surowcami Mineralnymi) t. 24, z. 4/1, s. 113-121.

Ratafia-Brown et al. 2002 - Ratafia-Brown J.A., Manfredo L.M., Hoffmann J.W., Ramezan M., 2002 - An environmental assessment of IGCC power systems. Nineteenth Annual Pittsburgh Coal Conference.

Song et al. 2010 - Song W., Lihua T., Zhu X., Wu Y., Zhu Y., Ko yama S., 2010 - Flow properties and rheology of slag from coal gasification. Fuel 89, p. 1709-1715.

Song et al. 2009 - Song W., Lihua T., Zhu X., Wu Y., Zhu Y., Koyama S., 2009 - Fusibility and flow properties of coal ash and slag. Fuel 88, p. 297-304.

Tang et al. 2010 - Tang Y., Yin H., Ren Y., Zhang J., 2010 - Preparation of Sialon Powder from coal gasification slag. Journal of Wuhan University of Technology-Materials Science Edition 25, p. 1044-1046.

CHARAKTERYSTYKA WYBRANYCH ODPADÓW ZE ZGAZOWANIA WĘGLA

\section{Słowa kluczowe}

Żużle i popioły, zgazowanie węgla, skład chemiczny, skład fazowy

\section{Streszczenie}

Polska jest krajem, w którym produkcja energii, ze względu na uwarunkowania surowcowe, jest i będzie oparta przede wszystkim na stosowaniu węgla. Jednak coraz bardziej rygorystyczne przepisy dotyczące ochrony środowiska wymuszają poszukiwanie nowych technologii zastosowania węgla do produkcji energii. Technologie

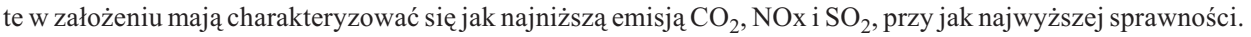

Jedną $\mathrm{z}$ testowanych i promowanych obecnie technologii jest zgazowanie węgla, co wynika $\mathrm{z}$ aktualnego poziomu rozwoju technologicznego. Zgazowanie węgla jest obiecującą technologią energetycznego wykorzystania węgla, przy zachowaniu coraz bardziej rygorystycznych norm ochrony środowiska, a zarazem przy zachowaniu wysokiej sprawności energetycznej. Technologia ta, jak każda wykorzystująca węgiel, powoduje powstawanie odpadów: popiołów lotnych i żużli. W przypadku zastosowania tej technologii na skalę przemysłową, powstające odpady będą musiały być w jakiś sposób zagospodarowane, najlepiej poprzez ich gospodarcze wykorzystanie. Popioły i żużle z procesów zgazowania węgla będą zaliczane do grupy odpadów energetycznych (grupa - odpady z procesów termicznych (10), podgrupa - odpady z elektrowni i innych zakładów energetycznego spalania paliw (10 01). W artykule przedstawiono charakterystykę badanych odpadów ze zgazowania dwóch żużli oraz popiołów lotnych, poprzez analizę ich składu chemicznego oraz fazowego. Badane odpady charakteryzują się wysoką zawartością $\mathrm{SiO}_{2}$ oraz niską zawartością $\mathrm{CaO}$. Badania składu fazowego metodą rentgenograficzną (XRD) i termograwimetryczną (DTA) wykazały wyłącznie substancje o charakterze amorficznym.

\section{CHARACTERISTICS OF SELECTED WASTES FROM CARBON GASIFICATION}

Key words

Slag and ash, coal gasification, chemical and phase composition

\section{Abstract}

Poland is a country where the production of energy, due to the availability of raw materials, is based mainly on coal. However, as environmental regulations become more and more stringent, it is necessary to seek new technologies to produce energy from coal. These new technologies are required to minimize the emission of $\mathrm{CO}_{2}$, 
$\mathrm{NOx}$, and $\mathrm{SO}_{2}$, and provide the highest possible efficiency. As a result of the latest technical developments, one popular method which is currently being tested is carbon gasification. Carbon gasification is a very promising technology for the continued use of coal for energy purposes, complying with strict environmental regulations and at the same time assuring high energy efficiency. Nevertheless, this technology, as with many others using coal, still produces waste in the form of slag and fly ash. Should this technology be implemented on an industrial scale, these byproducts will have to be either utilized or managed. Such wastes are categorized as energy waste (group thermal processes waste (10), subgroup - power plants and waste combustion plants (10 01). This article describes the characteristics of the tested waste from coal gasification - two types of slag and fly ashes - through the analysis of their phase and chemical composition. The tested wastes indicate high content of $\mathrm{SiO}_{2}$ and a low content of $\mathrm{CaO}$. The phase composition testing by X-ray diffraction method $(X R D)$ and thermogravimetric method $(D T A / T G)$ showed only substances of amorphous character. 